\title{
GC-MS Chemical Characterization of Main Components of Smilax Domingensis Wild. in Cuba
}

\author{
Pilar A. Soledispa \\ Faculty of Chemical Sciences, Guayaquil University, Ecuador. \\ José González (Corresponding author) \\ Department of Pharmacy, Faculty of Pharmacy and Foods, Havana University, Cuba. \\ E-mail: jgyaque@ifal.uh.cu \\ Armando Cuéllar \\ Department of Pharmacy, Faculty of Pharmacy and Foods, Havana University, Cuba.
}

Julio Pérez

Naional Center of Toxicology (CENATOX), Military Hospital "Carlos J. Finlay", Havana, Cuba.

\section{Max Monan}

Association pour la Recherche sur la Valorisation des Ressources Naturelles de la Martinique (ARVARNAM), 16 lot. les Rosiers, Quartier Thoraille, 97215, Rivière Salée, Martinique, France.

Received: March 29, 2018

doi:10.5296/jas.v6i2.13099
Accepted: April 13, 2018

URL: https://doi.org/10.5296/jas.v6i2.13099 


\section{Abstract}

A preliminary chemical characterization of main components of ethanolic extract with dried rhizomes of Smilax domingensis Wid. that grow in Cuba was done using a GCMS-QP2010 Ultra Shimadzu and the mass spectra of the compounds found in the extract was matched with the National Institute of Standards and Technology (NIST) library. After sample derivatization 125 chemical compounds were registered by the equipment and from them, 35 different chemical components were characterized and reported for the first time from this part of the plant in our country. The results demonstrate the developed method could be employed as a rapid and versatile analytical technique for identification of chemical constituents and quality control of Smilax domingensis.

Keywords: Smilax domingensis, chemical constituents, GC-MS, rhizomes, ethanolic extract.

\section{Introduction}

Smilax domingensis Willd., Smilacaceae, known as bejuco chino or raíz de china, zarzaparrilla de la tierra (Cuba); bejuco de membrillo, dunguez blanco (Puerto Rico); chiquihuite (México), is a climbing shrub from Tropical America. The rhizome is popularly used in medicine as anti-inflammatory, antiseptic, depurative, sudorific, antasthmatic, antiherpetic, antirheumatic and for venereal diseases (Roig, 2014).

Smilacaceae is a family of climbing shrubs represented by the single genus Smilax with close to 250 species worldwide, present with 26 species in Mesoamerica (Huft, 1994). Widely used since ancient times, the main species reported are Smilax aristolochiaefolia Mill., S. febrifuga Kunth, S. ornata Hook, and S. regelii Killip \& Morton, characterized by roots and small rhizomes used as antiseptic and anti-pruritic drug (British Herbal Pharmacopoeia, 1983).

Smilax domingensis Willd. is native from Tropical America, growing in lowlands, in humid forests of wide-leaved species (Standley \& Steyermark, 1952). Although widely used, there are several taxonomic difficulties. Few anatomic studies of American Smilax have been carried out, particularly for species from Argentina (Guaglianone \& Gattuso, 1991) and Brazil (Andreata, 1997).

In the scientific literature, there are some data of the phytochemical components and pharmacological actions while a small number of data of standards for identification and authentication about Smilax domingensis Willd. In Cuba, there is not available information for this spice. The main components found and shared by most species of the genus are the steroidal saponins, phytosterols, and triterpenoids (British Herbal Pharmacopoeia, 1983).

It is an evergreen dioic woody vine, 2-4 m high with lignified rhizomes. Rhizome is voluminous, with tuberous swelling, reddish brown in color, measuring $14-21 \mathrm{~cm}$ long, 3.925 $\mathrm{cm}$ wide and $3.175 \mathrm{~cm}$ high. The average weight is around $87.05 \mathrm{~g}$. Roots are adventitious, growing from the rhizomes (Figure 1). 


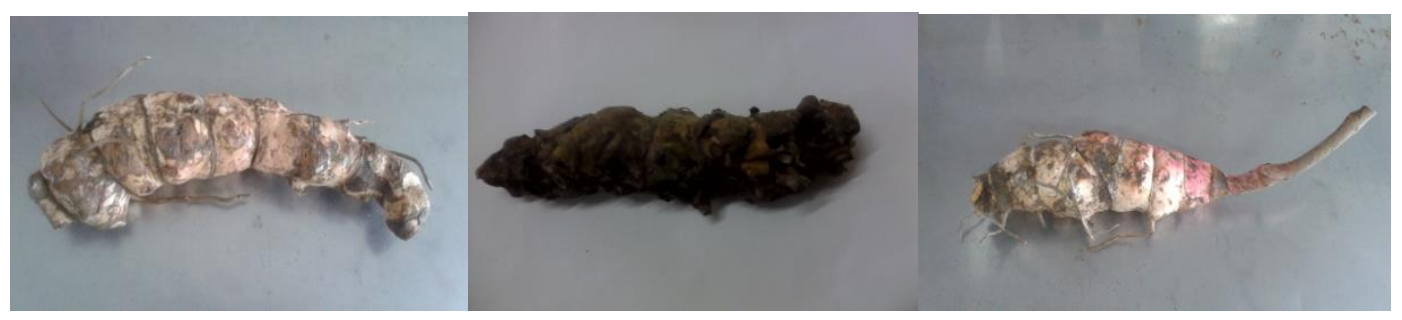

Fig. 1. Macroscopical view of rhizomes from S. domingensis Willd. in Cuba.

The aim of this research was to characterize the chemical composition of rhizomes of $S$. domingensis from our country for the development and utilization of the promising medicinal plant.

\section{Materials and Methods}

\subsection{Plant Material and Reagents}

The $S$. domingensis Willd. rhizome was collected from Sierra Cristal, Sagua de Tánamo, Holguín Province, Cuba, 850-1000 masl, by Elio M. García Fargie in March, 2016. The Voucher No. HAJB 089193 was registered at National Botany Garden in Havana, Cuba. The plant material was authenticated by Dr. Jorge E. Gutiérrez Amaro. The harvested rhizomes were dried in the shade at room temperature (temperature $30^{\circ} \mathrm{C}-40^{\circ} \mathrm{C}$ ) on the Research Lab Table in the Faculty of Pharmacy and Foods (Havana University), ground into powdered form $(1 \mathrm{~mm})$ and stored in airtight containers.

The extracts were prepared with the ground material $(60 \mathrm{~g})$ without screen extracted in a Soxhlet apparatus with $675 \mathrm{~mL}$ of ethanol at $95 \%$ during 20 hours. The ethanolic extracts were concentrated and evaporated under vacuum to $200 \mathrm{~mL}$ at $120 \mathrm{rpm}$, a temperature of $70^{\circ} \mathrm{C}$ and 500 mbar. All reagents used were of analytical grade (Merck). All solvents were degassed prior to use in an ultrasonic bath without filtration.

\subsection{HPLC Analysis}

HPLC analysis of ethanolic extract from the rhizomes was registered using an HPLC Knauer-Azura (Germany) equipped with an UV detector at $280 \mathrm{~nm}$. Chromatographic conditions: Flow (1 mL/min); Column (RP-18e Knauer 250 x 4.6 mm Lichrospher 100-5); Manual injection (50.00 $\mu \mathrm{L}$, twice); Running time (60 min); Pump pressure (11.7 MPa); Gradient (eluent A: water, eluent B: methanol, 15-85\% B during 30 min, follow by holding, increasing to $50 \%$ A during $10 \mathrm{~min}$, reversing to $0 \% \mathrm{~B}$ during $5 \mathrm{~min}$ and equilibrating during 5 min).

\subsection{GC-MS Analysis}

For the identification of metabolites present in the rhizomes, the sample were subjected to chromatographic analysis in equipment GC/MS, brand Shimadzu QP2010, equipped with a splitter split/splitless. With a BP5 $(30 \mathrm{~m} \times 0.25 \mathrm{~mm} \times 0.25$ microns $)$ capillary column under the following chromatographic conditions: Helium gas carrier obtained by electron impact fragments to a power of $70 \mathrm{eV}$ rate of $1.2 \mathrm{~mL} / \mathrm{min}, 1: 50$ split flow and the volume of injected 


\section{Macrothink}

Journal of Agricultural Studies

ISSN 2166-0379

2018, Vol. 6, No. 2

sample of $1 \mathrm{ul}$. Programmed oven temperature: initial temperature was $70^{\circ} \mathrm{C}$ with a heating ramp of $10^{\circ} \mathrm{C} / \mathrm{min}$ to $300^{\circ} \mathrm{C}$ and remained stable at this temperature for 10 minutes. Subsequently the temperature was increased at a rate of $10^{\circ} \mathrm{C} /$ minute to $300^{\circ} \mathrm{C}$ for a total time of 78 minutes with an injector temperature $250^{\circ} \mathrm{C}$ and the interface temperature $300^{\circ} \mathrm{C}$.The compounds were analyzed using GC/MS NIST21 and NIST107 library and having into account the results obtained after phytochemical screening according with González et al. (2017). Silylation agent was N, O-bis (trimethylsilyl) trifluoroacetamide (BSTFA) CAS 25561-30-2 Lot: 0901-1 Macherey-Nagel GmbH \& C. KG.

\subsection{Data Analysis}

Comparison of the spectra with the NIST database using a probability-based matching algorithm was performed to achieve compound identification, along with comparison of relative retention indices (RI) to literature and standard reference values.

\section{Results and Discussion}

\subsection{Chromatographic profile by HPLC}

From rhizomes, 34 peaks in HPLC-UV chromatogram were identified as shown in figure 2. Their retention times were between 2.550 and 48.283 minutes, although the chromatogram resolution is not the most ideal after this retention time and up to 50 minutes, which allow us inferred that there are other components into analyzed sample. The most prominent peaks belongs to compounds 1 (2.550 $\mathrm{min}), \mathbf{3}$ (3.333 $\mathrm{min}), \mathbf{2 0}$ (26.517 $\mathrm{min}), 21$ (27.383 $\mathrm{min}), \mathbf{2 2}$ (28.267 $\mathrm{min}$ ) and 24 (29.950 $\mathrm{min})$, giving an idea that they are the majoritarian chemical components in the sample. Around peak 33 (45.400 min) and 34 (48.3 $\mathrm{min})$ the chromatogram show another prominent area indicating the presence of several components but this zone have not a good resolution.

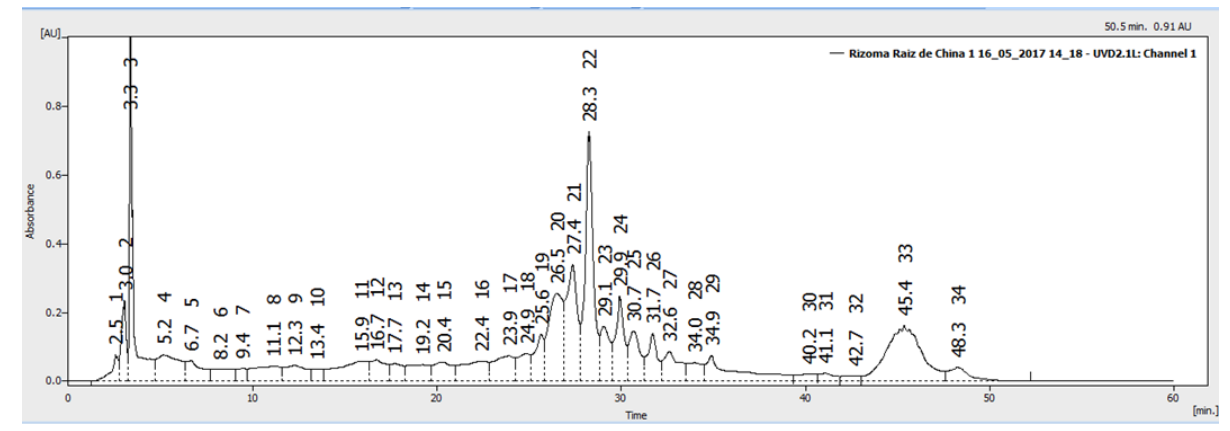

Fig. 2. Chromatographic profile by HPLC of rhizomes of $S$. domingensis Willd. 


\subsection{Chemical characterization by GC-MS}

Preliminary phytochemical screening suggested the presence of flavonoids, alkaloids, coumarins, catechins, pirochatecolic tannins, fat and/or volatile oils, saponins, triterpens and/or steroid, quinones and reducing sugars, and the absence of resins, amino acids or amines, cardiotonic glycosides, anthocyanidins and astringents and/or bitter principles Data referred here refer to evaluations with wild material in our country (Yaque et al., 2017).

The peaks are marked with retention time in the GC-MS chromatogram of ethanolic extract of the rhizome from $S$. domingensis. Their retention times (RT) and their corresponding names are listed in Table 1. The qualitative analysis of the ethanolic extract showed the presence of 125 different kinds of chemical compounds according with the equipment database (Fig. 3) and among them; only 35 received the proposal of chemical characterization. The first 23 chemical compounds were discarded because they are related with the Silylation agent and their derivatives.

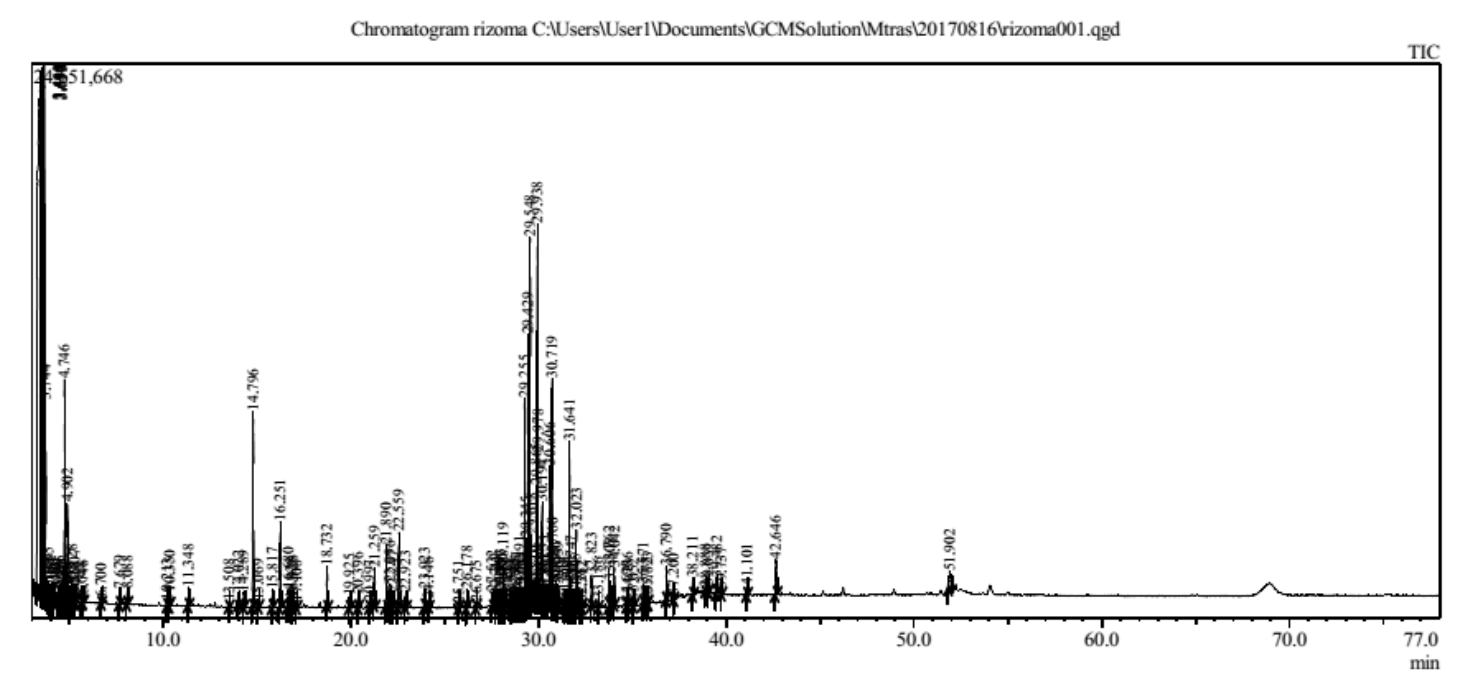

Fig. 3. GC chromatogram of rhizomes from S. domingensis Willd.

Most of the chemical components belong to organic acids, reductants sugars, and lactones and relative compounds. The chemical matches were around $80 \%$ of coincidence with NIST21 and NIST107 libraries. 
Table 1. Chemical components characterized by GC-MS in rhizomes of S. domingensis.

\begin{tabular}{|c|c|c|c|c|c|c|}
\hline Peak \# & R.Time & Molecular formula & $\begin{array}{l}\text { Molecular } \\
\text { weight }\end{array}$ & $\begin{array}{l}\text { Base } \\
\text { Peak }\end{array}$ & CAS & Library ID/Compound Name ${ }^{*}$ \\
\hline 1 & 14.794 & $\mathrm{C}_{12} \mathrm{H}_{32} \mathrm{O}_{3} \mathrm{Si}_{3}$ & 308 & 73.00 & $6787-10-6$ & Trimethylsilyl ether of glycerol \\
\hline 2 & 15.824 & $\mathrm{C}_{10} \mathrm{H}_{22} \mathrm{O}_{4} \mathrm{Si}_{2}$ & 262 & 147 & $40309-57-7$ & Butanedioic acid (Succinic acid) \\
\hline 3 & 16.251 & $\mathrm{C}_{9} \mathrm{H}_{20} \mathrm{O}_{4} \mathrm{Si}_{2}$ & 276 & 147 & $55557-24-9$ & Propanedioic acid \\
\hline 4 & 16.682 & $\mathrm{C}_{12} \mathrm{H}_{30} \mathrm{O}_{4} \mathrm{Si}_{3}$ & 322 & 73 & $38191-87-6$ & Propanoic acid, 2,3-bis[(trimethylsilyl)oxy \\
\hline 5 & 15.815 & $\mathrm{C}_{10} \mathrm{H}_{22} \mathrm{O}_{3} \mathrm{Si}_{2}$ & 246 & 147 & $55590-70-0$ & 2-Butenoic acid \\
\hline 6 & 16.683 & $\mathrm{C}_{9} \mathrm{H}_{22} \mathrm{O}_{3} \mathrm{Si}_{2}$ & 234 & 147 & $55162-32-8$ & Propanoic acid \\
\hline 7 & 18.735 & $\mathrm{C}_{13} \mathrm{H}_{30} \mathrm{O}_{5} \mathrm{Si}_{3}$ & 350 & 73.00 & $65143-63-7$ & Malic acid \\
\hline 8 & 21.260 & $\mathrm{C}_{14} \mathrm{H}_{32} \mathrm{O}_{5} \mathrm{Si}_{3}$ & 364 & 73 & $0-00-0$ & 3-Hydroxy glutaric acid \\
\hline 9 & 22.097 & $\mathrm{C}_{12} \mathrm{H}_{28} \mathrm{O}_{3} \mathrm{Si}_{2}$ & 276 & 73 & $54890-08-3$ & Pentanoic acid, 4-methyl-2-[(trimethylsilyl)oxy] \\
\hline 10 & 22.935 & $\mathrm{C}_{16} \mathrm{H}_{42} \mathrm{O}_{4} \mathrm{Si}_{4}$ & 410 & 73 & $32381-52-5$ & Threitol \\
\hline 11 & 26.181 & $\mathrm{C}_{14} \mathrm{H}_{32} \mathrm{O}_{5} \mathrm{Si}_{3}$ & 364 & 73 & $10589-37-4$ & Arabinoic acid, 2,3,5-tris-O-(trimethylsilyl)-, .gamma.-lactone, 1 \\
\hline 12 & 27.537 & $\mathrm{C}_{14} \mathrm{H}_{32} \mathrm{O}_{5} \mathrm{Si}_{3}$ & 364 & 73 & $32384-55-7$ & D-Arabinonic acid, 2,3,5-tris-O-(trimethylsilyl)-, .gamma.-lactone \\
\hline 13 & 28.073 & $\mathrm{C}_{18} \mathrm{H}_{42} \mathrm{O}_{6} \mathrm{Si}_{4}$ & 466 & 73 & $0-00-0$ & 2-Methyl-2,4-bis(trimethylsilyloxy)bis(trimethylsilyl)glutarate \\
\hline 14 & 28.121 & $\mathrm{C}_{20} \mathrm{H}_{52} \mathrm{O}_{5} \mathrm{Si}_{5}$ & 512 & 73 & $14199-72-5$ & Xylitol, 1,2,3,4,5-pentakis-O-(trimethylsilyl) \\
\hline 15 & 28.998 & $\mathrm{C}_{17} \mathrm{H}_{42} \mathrm{O}_{5} \mathrm{Si}_{4}$ & 438 & 217 & $56271-69-3$ & D-Ribofuranose \\
\hline 16 & 29.251 & $\mathrm{C}_{19} \mathrm{H}_{46} \mathrm{O}_{6} \mathrm{Si}_{4}$ & 482 & 217 & $6736-96-5$ & Glucofuranoside, methyl 2,3,5,6-tetrakis-O-(trimethylsilyl) \\
\hline 17 & 29.347 & $\mathrm{C}_{17} \mathrm{H}_{42} \mathrm{O}_{5} \mathrm{Si}_{4}$ & 438 & 73 & $55555-45-8$ & D-Xylopyranose \\
\hline 18 & 29.434 & $\mathrm{C}_{21} \mathrm{H}_{52} \mathrm{O}_{6} \mathrm{Si}_{5}$ & 540 & 217 & $19126-98-8$ & D-Fructose \\
\hline 19 & 29.547 & $\mathrm{C}_{22} \mathrm{H}_{52} \mathrm{O}_{7} \mathrm{Si}_{5}$ & 568 & 217 & $27531-31-3$ & $\begin{array}{l}\text { D-Glycero-L-manno-Heptonic acid, } \\
\text { 2,3,5,6,7-pentakis-O-(trimethylsilyl)-, .gamma.-lactone }\end{array}$ \\
\hline 20 & 29.813 & $\mathrm{C}_{18} \mathrm{H}_{44} \mathrm{O}_{5} \mathrm{Si}_{4}$ & 452 & 73 & $0-00-0$ & 2-Deoxy-galactose \\
\hline 21 & 29.866 & $\mathrm{C}_{21} \mathrm{H}_{52} \mathrm{O}_{6} \mathrm{Si}_{5}$ & 540 & 73 & $6736-94-3$ & D-Galactose \\
\hline 22 & 29.979 & $\mathrm{C}_{21} \mathrm{H}_{52} \mathrm{O}_{6} \mathrm{Si}_{5}$ & 540 & 217 & $7045-52-5$ & beta.-D-Galactofuranose \\
\hline 23 & 30.193 & $\mathrm{C}_{21} \mathrm{H}_{52} \mathrm{O}_{5} \mathrm{Si}_{5}$ & 524 & 73 & $114656-62-1$ & Myo-inositol, 5-deoxy-1,2,3,4,6-pentakis-O-(trimethylsilyl) \\
\hline 24 & 30.258 & $\mathrm{C}_{14} \mathrm{H}_{30} \mathrm{O}_{5} \mathrm{Si}_{3}$ & 362 & 73 & 72361-20-7 & Pentanedioic acid, 3-oxo-, tris(trimethylsilyl) ester \\
\hline 25 & 30.770 & $\mathrm{C}_{21} \mathrm{H}_{52} \mathrm{O}_{6} \mathrm{Si}_{5}$ & 540 & 204 & $6736-97-6$ & D-Glucose \\
\hline 26 & 30.940 & $\mathrm{C}_{21} \mathrm{H}_{50} \mathrm{O}_{6} \mathrm{Si}_{5}$ & 538 & 73 & $14251-19-5$ & Inosose \\
\hline 27 & 31.749 & $\mathrm{C}_{17} \mathrm{H}_{42} \mathrm{O}_{5} \mathrm{Si}_{4}$ & 438 & 217 & $56271-64-8$ & beta.-DL-Arabinopyranose \\
\hline 28 & 31.982 & $\mathrm{C}_{20} \mathrm{H}_{50} \mathrm{O}_{6} \mathrm{Si}_{5}$ & 526 & 73 & $57197-35-0$ & Ribonic acid \\
\hline 29 & 32.030 & $\mathrm{C}_{19} \mathrm{H}_{40} \mathrm{O}_{2} \mathrm{Si}$ & 328 & 73 & $55520-89-3$ & Hexadecanoic acid \\
\hline 30 & 33.765 & $\mathrm{C}_{21} \mathrm{H}_{40} \mathrm{O}_{2} \mathrm{Si}$ & 352 & 75 & $56259-07-5$ & 9,12-Octadecadienoic acid \\
\hline 31 & 33.810 & $\mathrm{C}_{21} \mathrm{H}_{42} \mathrm{O}_{2} \mathrm{Si}$ & 354 & 73 & $21556-26-3$ & Oleic acid \\
\hline 32 & 34.042 & $\mathrm{C}_{21} \mathrm{H}_{44} \mathrm{O}_{2} \mathrm{Si}$ & 356 & 73 & $18748-91-9$ & Octadecanoic acid \\
\hline 33 & 35.574 & $\mathrm{C}_{21} \mathrm{H}_{50} \mathrm{O}_{7} \mathrm{Si}_{5}$ & 554 & 73 & $55530-80-8$ & D-Glucuronic acid \\
\hline 34 & 36.789 & $\mathrm{C} 24 \mathrm{H} 38 \mathrm{O} 4$ & 390 & 149 & $117-81-7$ & 1,2-Benzenedicarboxylic acid, bis(2-ethylhexyl) ester \\
\hline 35 & 42.644 & $\mathrm{C}_{16} \mathrm{H}_{32} \mathrm{O}_{4} \mathrm{Si}_{3}$ & 372 & 255 & $0-00-0$ & 4,6-Dioxohept-2-enoic acid, tri-TMS \\
\hline
\end{tabular}

*The nearest library standards. 
Alkaloids, antraquinones, flavonoids, catechins, tannins or phenolic compounds, saponins and triterpenes or steroids were not detected. It is evident from this information that the chemical composition of $S$. domingensis in Cuba. Contrary to expected according to the literature, sarsapogenin, smilagenin or steroids (stigmasterol, $\beta$-sitosterol and cholesterol) were not detected by GCMS analysis, according to the molecular masses of known saponins from S. officinalis (Cáceres et al., 2012). It is evident from this information that the chemical composition of $S$. domingensis in Cuba is different from that of $S$. domingensis rhizome found in Guatemala.

These results by GC/MS are not agree with the results of phytochemical screening and TLC found by the authors in 2017 with the same sample in ethanolic extract when preliminary chemical characterization allow to suggested the presence of flavonoids, alkaloids, coumarins, catechins, pyrochatecolic tannins, fat and/or volatile oils, saponins, triterpens and/or steroid, quinones and reducing sugars, and the absence of resins, amino acids or amines, cardiotonic glycosides, anthocyanidins and astringents and/or bitter principles.

TLC results evidenced the presence of chemical compounds type flavonoids, some structures related with terpenoids structures and the presence of phenolic compounds derives from catechol (Yaque et al., 2017). Further studies are needed to establish the molecules responsible for the chemical composition and the biological activities attributed to this rhizome, specially using HPLC-MS or LC-NMR. Toluene extract is still pendant to characterize by some appropriated method waiting to improve the real composition of chemical components of this promising medicinal plant.

\section{Conclusions}

GC-MS is frequently applied to characterize the chemical complexity of analytical samples based on its separation and identification capacity. Smilax domingensis Willd., Smilacaceae, known as zarzaparrilla, is a climbing shrub from Tropical America. The rhizome is popularly used in medicine as anti-inflammatory, antiseptic, and tonic. Following solvent extraction and derivatization, 35 metabolites from different chemical groups can be characterized in one analytical run. Besides sugars, acids, and polyols, diverse derivatives and other cyclic metabolites can be efficiently detected by metabolite profiling. The results from plant research to exemplify the applicability of GC-MS profiling and concurrent detection and identification of three principal groups of chemical components and other cyclic structures. Based on experimental data from own research, the present review has emphasized the capabilities of GC-MS to deduce chemical information on diverse compounds found in complex mixtures of plant metabolites. The compounds identified can be also used as biomarkers especially for $S$. domingensis due to little research has been published for this species. This is the first time that the chemical composition of $S$. domingensis rhizome in Cuba is described.

\section{Conflict of Interest}

The authors declare no conflict of interest. 


\section{References}

Roig, J. T. (2014). Plantas Medicinales Aromáticas y Venenosas de Cuba. Editorial Científico Técnica, La Habana, 671-672.

Huft, M. J. (1994). Smilacaceae. In: Devidse, G., Sousa, M. and Chater, A.O., Eds., Flora Mesoamericana, Universidad Nacional Autónoma de México, México, Missouri Botanical Garden y the National History Museum, London, 20-25.

British Herbal Pharmacopoeia (1983). Bournemouth. The British Herbal Medicine Association, 197-198.

Standley, P. C. and Steyermark, J. A. (1952). Flora of Guatemala. Fieldiana: Botany, 24, 92-100.

Guaglianone, E. R. and Gattuso, S. (1991). Estudios taxonómicos sobre el género Smilax (Smilacaceae). Boletín de la Sociedad Argentina de Botánica, 27, 105-129.

Andreata, R. H. P. (1997). Revisão das espécies brasileiras do genero Smilax Linnaeus (Smilacaceae). Pesquisas em Botânica, 47, 1-243.

Yaque, J. G., Monan, M., Cuéllar, A., de Armas, T., Gómez, E. and Dopico, E. (2017). Pharmacognostic and Phytochemical Studies of Smilax domingensis Willd. in Cuba. American Journal of Plant Sciences, 8, 1462-1470. https://doi.org/10.4236/ajps.2017.86100

Cáceres, A., Cruz, S. M., Martínez, V., Gaitán, I., Santizo, A., Gattuso, S. and Gattuso, M. (2012). Ethnobotanical, Pharmacognostical, Pharmacological and Phytochemical Studies on Smilax domingensis in Guatemala. Revista Brasileira de Farmacognosia, 22, 239-248.

https://doi.org/10.1590/S0102-695X2011005000211

\section{Copyright Disclaimer}

Copyright for this article is retained by the author(s), with first publication rights granted to the journal.

This is an open-access article distributed under the terms and conditions of the Creative Commons Attribution license (http://creativecommons.org/licenses/by/4.0/). 